\title{
Baby Care: A Lesson from the Gurage of Ethiopia
}

\author{
Iyasu Angani Dereja* \\ Animal Products, Veterinary Drug and Feed Quality Assessment Center (APVDFQAC), Ethiopia
}

Submission: January 30, 2018; Published: February 12, 2018

*Corresponding author: Iyasu Angani Dereja, Animal Products, Veterinary Drug and Feed Quality Assessment Center (APVDFQAC), Ethiopia, Email: iyasuangani@uopeople.edu

\section{Abstract}

This mini review is concerned with the health aspects of baby care culture in one of the indigenous societies, the Gurage. After describing the trend kept, it tries to illustrate the benefits of such practice as it relates metal and social health.

Keywords: Gurage; Baby care; Indigenous; Health benefits

\section{Introduction}

According to the World Health Organization [1], health is defined as "the state of complete physical, mental and social wellbeing". While all the three dimensions are critically important, the later two seems to be more lasting.

Mental and social wellness of a person depends in many aspects, of which factors determining perception of the world are the major ones. Parenting is introduction of the world to the children through their mothers and/or elders. Anything they faced during that time is first impression.

The main reason being denied attention, there are numerous practices in the native society that are both scientifically acceptable and economically feasible. The objective of this article, thus, is to glimpse an indigenous child nursing practice in the Gurage as it pertains to mental and social health.

\section{Overview of the gurage and their culture}

Gurage, iconic people of Ethiopia, are known for their unique characteristics from various perspectives. While they are particularly identified as 'the most industrious nationals of the country based on their business culture, they are also popular for other dimensions such as indigenous topography design, leisure and dance, legal procedure, social structure, food and medicinal artifacts and psychotherapy [2-4].

Many researchers in the area link these triumphs with the childhood development trend in the society. As the contemporary science contends, we all are building on our early understandings of the world. How we perceived problems seldom developed at later ages. This is especially important when it comes to nontherapeutic medicine and principle of natural nursing. That's why we loved to discover baby nursing in the society. The next sections of this article try to illustrate baby care and child development in Gurage, and the way this pertains to the nursing world.

\section{How children are nursed in gurage}

In Gurage, a mother that gave birth is expected to be homed at least for two months. During this period, she stays in a shade with special treatment. One more assistant look after her and she is fed high quality meals.

Unless she wants to exercise and examine herself with simple tasks such as a few minutes walking, she is not expected to do works. Her major errand at this period is to look after her newborn. With undivided attention, she ensures that her baby is well nourished. In addition to feeding and looking after its health, this is a calm time to craft a vision on which the later mission of the baby is built.

Although it is primarily the mother's concern to care for a child in Gurage, as to other society, responsibility gradually shifts to brothers and/or sisters. After two to six months of period, she has to go back to her regular activity. This time, another child (if any), even if too little-as little as two years-is required to look after their younger brother/sister. As they grow, they are allowed to go out of home and enjoy the day everywhere in the village including neighbors' and relatives' homes, gardens and graze lands. May these practices have benefit? What are they important for? The following paragraphs answer.

\section{Health Benefits of the Practice}

\section{Psychological}

For the newborn, to enjoy a long time stay, and having undivided attention of his families, is a fertile ground to know 
this world as the place of peace and love. As psychology studies preach, having time together is the most successful way to establish strong connection [5].

As it is forward to imagine, while in the hug of its mother, and of its brother/sister later, the baby is prone to affection. In its first contact with the world, the baby develops a mentality of being cared, loved, and valued. When grown, it is this love that she/he wants to do the same for the next generation. It is this trend that kept the Gurage family strongly associated with one another.

\section{Social}

As the mother and brothers and/or sisters are the first 'ambassador of this world' for it, the baby recognizes the world as a place of love, peace and cooperation. This grows into a strong social tie which is demonstrable in various aspects of the community.

In addition to cooperative business, the Gurage are known for their negotiation skills, ability to adapt cultural and geographical differences and establish relatively lasting networks. Ekub and Edir, social aid and safety net systems - which are believed to be bases for the modern banking and insurance systems, and are still widely practiced in the country-are believed to be originated from this community.

\section{Recommendation and Conclusion}

Such social and psychological health manifestations are just indications. At the background are strong and indigenously established care and child development systems. While other factors are also unexcluded, childhood development plays a major role in social and mental health of persons in Gurage culture. As suggested by the world health organization definition of health, these should be recognized, protected and practiced well.

\section{References}

1. World Health Organization (2018) Frequently asked questions. Geneva, Switzerland.

2. Britannica (2018) Gurage people.

3. CSA (2012) 2007 population and housing census of Ethiopia: Administrative report. Addis Ababa, Ethiopia.

4. Ford C (2018) The Gurage people.

5. Chapman G (2004) The five love languages: how to express heartfelt commitment to your mate. Northfield publishing, Chicago, USA.

\begin{tabular}{l} 
Your next submission with Juniper Publishers \\
will reach you the below assets \\
- Quality Editorial service \\
- Swift Peer Review \\
- Reprints availability \\
- E-prints Service \\
- Manuscript Podcast for convenient understanding \\
- Global attainment for your research \\
- Manuscript accessibility in different formats \\
( Pdf, E-pub, Full Text, Audio) \\
- Unceasing customer service \\
Track the below URL for one-step submission \\
https://juniperpublishers.com/online-submission.php \\
\hline
\end{tabular}

